\title{
Homo Economicus or Homo Ludens? A Survey of the Behavioral Motives of German Investors
}

\author{
Gerhard Raab \\ Ludwigshafen University of Applied Sciences, Ludwigshafen, Germany \\ L. W. Murray \\ University of San Francisco, San Francisco, USA
}

\begin{abstract}
Why do investors invest? Are they "rational" in their decisions? Do experienced investors make investment decisions that are different from those made by novice investors? This paper provides the results of a survey of over 1,000 German investors, which are selected randomly. These investors apparently invest in equity securities for a number of reasons, with the potential for economic gain foremost. However, several other motives are also provided, and in most cases these investors pursued multiple motives.
\end{abstract}

Keywords: homo economicus, homo ludens, Germany, behavioral finance investment motives

\section{Overview}

Economic theory assumes rational behavior among economic players. In the paradigm of modern capital markets theory - which has essentially been characterized by the so-called capital market model since the 1960s - there is only one motive for people to invest money: they want to turn a profit. The underlying archetypal persona can be found in the imaginary homo economicus. Observing actual events on many markets, however, it appears that observed behaviors are difficult to explain with exclusive reference to the assumptions and implications of the homo economicus. In some cases, behaviors are even contradictory. Taking an empirical approach to the behavior of economic players, anomalies become apparent that can hardly be brought into accord with the assumptions associated with the homo economicus.

This is why scientists repeatedly discuss whether it would be better to put an end to this economic, amoral monster (or analytical freak) (Wunderlich, 1989, pp. 9-21). Just as intense are the arguments in favor of this exemplary construct devoid of all personality traits as an archetype and mental figure to explain social and economic structures, processes, action outcomes, mindsets, behaviors, decision making, and planning strategies. What is certain is that observed behavior contradicts this model's assumptions in many instances. Such inconsistencies are not merely exceptions, they are in fact the rule: in the majority of cases, people taking economic action behave differently than economic theory assumes. This necessitates an expanded approach that includes psychological insights stemming from the late 1980s within the field of behavioral finance (DeBondt \& Thalser, 1994; Nitzsch \& Friedrich, 1999a, 1999b; Shefrin, 2000; Schiller, 1997; Wärneryd, 2001). This

Gerhard Raab, Ph.D., Professor of Marketing, Ludwigshafen University of Applied Sciences.

L. W. Murray, Emeritus Professor of Finance, University of San Francisco.

Correspondence concerning this article should be addressed to L. W. Murray, 1894 15th Avenue, San Francisco, CA 94122 USA.E-mail: murray@usfca.edu. 
discipline examines phenomenon for which a stringent economic perspective offers no explanation.

A core topic in behavioral finance is the individual-based psychological examination of the less rational but actual decision making behavior of market participants. To this end, economic and psychological insights are linked on the basis of a behavioral science paradigm. The focus does not lie on monetary flows, but on people, their behavior, and their motives. This leads, for instance, to the insight that behavior on stock exchanges can be explained to a substantial extent by the players' feelings and moods.

This article focuses on investigating the motives that prompt private investors to invest their money in shares on capital markets. Greater insight into the motives makes it possible to better understand, explain, and predict investment behavior. The point of departure for this article is the thesis that financial investment decisions on the part of investors can also be viewed as a game-or even as gambling. With this, homo economicus is juxtaposed with another archetype: homo ludens (Huizinga, 1938). Here, it is not about replacing one limited image of humanity with another, presumably just as limited. The intent is to illustrate that the behavior of people is not generally motivated by economic factors alone, but by numerous other non-economic and in this sense irrational factors. After further identifying the two concepts this article then undergoes empirical examination based on a representative survey of the German population.

\section{Preliminary Remarks on the Homo Economicus Concept}

The homo economicus archetype, as described by Smith (1776), is prevalent in economic science and in sociology, law, etc. It centers on an ideal of an individual who thinks and acts thoroughly rationally, upon which numerous economic theories build. Even practical recommendations-such as assembling optimal portfolios—systematically assume this rationality.

Critiquing the mental image of homo economicus becomes all the more difficult since the characteristics of this figure are in no way as unambiguously defined as it would first appear (Manstetten, 2000). Notions of whom or what this homo economicus actually is diverge dramatically. On the substantive level, it remains unclear to what extent homo economicus can be described as rational. Also under debate is whether or not homo economicus must be presumed to be egotistical, and if so, whether this egotism does not also encompass altruism. The derivation remains controversial: Does it represent a simplification of experiences that would call for immediate evidence, or should homo economicus largely be considered a construct within a sterile model environment? Finally, the scope is also unclear: Is the concept from the economic world limited or can it also be used to explain other areas of human activity, as Becker (1994) did by applying it to the area of the family?

More concise definitions can be found in literature, in which, for example, maximizing the target function is presumed along with other less restrictive definitions. It suffices to say that homo economicus behaves as a "satisfier" and investigates the alternatives accessible to him until he finds a sufficiently acceptable one (Kirchgässner, 2001). Nitzsch and Friedrich (1999a, p. 1) describe homo economicus using the following characteristics:

- He is fully informed. His perception of market data is comprehensive and undistorted. He condenses this data into market information;

- He is exclusively benefits-oriented. He reaches all decisions based on this objective;

- He decides unemotionally. Feelings like fear or states of excitement are completely foreign to him.

It is obvious that scientific assumptions must always be abstracted from reality in a certain way and thus 
can also be disproved in individual cases. What is decisive, however, is that this does not take place systematically and that key aspects remain intact during the abstraction process.

When comparing economic theory with insights from psychology, it becomes apparent that the basic principles of homo economicus do not fundamentally contradict the psychological perspective. As Kirchgässner (2001, p. 30) posed, the psychological theory behind the economic approach is, for example, equivalent to the social-psychological value-expectation theory as argued by Feather (1959, pp. 150-164) for example. Notwithstanding, individual attributes of the economic behavior model diametrically contradict psychological insights, making it difficult to salvage the homo economicus model without completely disavowing reality. Experimental economic research has shown this repeatedly (Hillen, 2003). This also holds true when applying less restrictive assumptions. It applies that when looking at the motives of market players in those areas in which the model's assumptions could be best fulfilled because a certain level of transparency exists and the target functions of players are more quantifiable than in other areas. Such areas reveal the true financial investment behavior of private investors.

\section{Economic Capital Markets Theory and Behavioral Finance}

The homo economicus assumptions also underlie economic capital markets theory. According to it, players on capital markets behave rationally in that they intend to invest their money profitably (Fama, 1970, 1998; Lintner, 1965; Sharpe, 1964; Malkiel, Multhatha, \& Stangle, 2005). Other motives are not considered. In this way, the most profitable form of investment is selected or a portfolio is composed from all available forms of investments that reflect the investor's preferences. Psychological aspects, emotions, and moods among market participants are endogenized and not taken into consideration in the models.

For more than 40 years psychologists steadily developed research on this topic, indicating that the presumed and modeled individuals in capital markets theory have little in common with the observable behaviors of financial investors. Decisive contributions have been made in recent decades, primarily by Kahneman and Tversky (1972, 1973, 1974, 1979, 1981, and 1991). Capital markets research based on behavioral sciences thus distances itself from the rationality premises of classic economic capital markets theory and centers on the psychological analysis of the individual to then be able to infer the effects in the market. Table 1 provides an overview of several assumptions of classic financial theory that are contradictory to actual investor behavior.

Table 1

Assumptions vs. Actual Investor Behavior

\begin{tabular}{|l|l|}
\hline Postulates of classic capital markets theory & Insights from behavioral finance \\
\hline Individuals act rationally in the sense of homo economicus & $\begin{array}{l}\text { Emotions, market moods, herding behavior (limited rational } \\
\text { behavior) }\end{array}$ \\
\hline Players are always fully informed & $\begin{array}{l}\text { layers are not fully informed, information is perceived and } \\
\text { processed selectively }\end{array}$ \\
\hline Investors hold diversified portfolios & $\begin{array}{l}\text { Lack of diversification; personal favorites show } \\
\text { disproportionately high weighting }\end{array}$ \\
\hline $\begin{array}{l}\text { Actively managing shares (in contrast to mutual funds) does } \\
\text { not generally make sense }\end{array}$ & Actively managed shares are widely popular \\
\hline $\begin{array}{l}\text { Investors act only when there is new information, a change in } \\
\text { assets, or a change in their risk attitude }\end{array}$ & $\begin{array}{l}\text { The actual trading volume is too high to be explained by the } \\
\text { theoretical assumptions }\end{array}$ \\
\hline Individual errors are reconciled & Individual errors are aggregated \\
\hline
\end{tabular}




\section{Anomalies in the Behavior of Economic Players}

In the homo economicus model, an idealized notion of rationality is assumed for market participants that only a computer can show in the ideal case. Assumed is that each market participant systematically absorbs undistorted information, then processes and evaluates it without the psyche hindering this process in any way. As a logical consequence, theories building on this premise can neither explain nor predict psychological effects in the market. Numerous studies have been conducted to investigate actual human behavior. In many places, they reach the conclusion that people in no way consistently maximize their individual benefit. They are subject to decision anomalies and, in this sense, systematically act irrationally. Financial decision making behavior is particularly well researched. Results reveal behavioral patterns that systematically deviate from the behavioral assumptions postulated by the homo economicus model. From the model perspective, these significant deviations from homo economicus premises are anomalies. Several of these deserve brief description (Kiehling, 2001; Pelzmann, 2000; Rossbach, 2001):

(1) Selective and social perception. Market players in no way perceive all information. They make a selection among the information offered. To reduce the complexity of decision making situations, information that at first seems unimportant is disregarded. Beyond this: given extensive information, it is primarily only the information in line with a player's own ideas and opinions that is perceived. Contradictory information is, in contrast, repressed or ignored. Particularly for decisions already reached, information is selected in such a way to shed a positive light on that decision. This selective perception can take place consciously or unconsciously.

(2) Overestimation of own capabilities. People have a pronounced need for control. They feel at ease when they have control and uneasy when they perceive a control deficit (Nitzsch, Friedrich, \& Pulham, 2001). In some cases, this leads to an illusion of control (Langer, 1975). The subjective feeling of being in control of a situation has pivotal influence over the extent of overestimation (Griffin \& Varey, 1996; Lichtenstein, Rischhoff, \& Philips, 1982). Not only do investors succumb to overestimation of their capabilities, this applies to financial markets, too (Stotz \& Nitzsch, 2002). Illusions of control and overestimation of capabilities can be observed on capital markets in two variants: active and frequent trading on the one side, and the selective choice of shares on the other side (Barber \& Odean, 2001). In both cases, investors believe that they can generate returns in excess of those a passive investment would yield based on their own capabilities.

Langer (1975) and Langer and Roth (1975) posed the hypothesis that illusion of control and overestimation of capabilities not only emerges in capabilities-dependent situations, but also in situations dependent on chance such as gambling and clear evidence supports this. For example, test subjects were willing to pay around four times the price for a raffle ticket if they could choose the ticket number themselves. They were convinced that the odds of winning were higher if they could influence the situation.

(3) Loss aversion. Loss aversion expresses the empirically backed observation that people generally perceive a loss more intensely than a gain of the same magnitude (Kahneman \& Tversky, 1979). To illustrate, a situation in which nothing is lost or gained is perceived as more pleasant than a situation in which 100 euros are won in one engagement while 100 euros are lost in another. This tendency to persist in holding investments already made, even given negative developments, in order to avoid having to recognize a loss - even though promising alternatives exist. Realizing the loss would rob investors of the opportunity of still closing out the "mental account" associated with the investment with a gain. Instead, people utilize the principle of selective perception to find information that justifies the decisions they have reached. Due to the stronger perception of 
losses, gains are consequently frequently realized too soon.

(4) Judgment heuristics. The availability heuristic describes the phenomenon that market players more frequently access easily available information (Kahneman \& Tversky, 1973). In this way, current, easily accessible, particularly conspicuous, and easily understood information tends to be overrated (Oehler, 1992). One example is the "home bias" phenomenon that describes a clear overweighting of the home market when investing in shares. Private German investors place around 85 percent of their assets in home market equities, in the US, this figure even reaches 95 percent. Not only do investors believe they know their home market better, they associate higher returns and lower risk with their own market. As a consequence, less familiar but more promising markets are neglected (Kahneman \& Tversky, 1974). In doing so, investors often base their judgments, estimates, and forecasts too strongly on an initial value like the purchase price of a share that for them serves as a reference point or anchor. Adjustment of the initial value based on available information is most often insufficient. The anchoring heuristic also explains the correlation between the classification of information and both perception type and context. Thus, the sequence or way in which information is presented can substantially influence how information is processed. In unclear situations, points of reference are also frequently applied that have no bearing on the issue but happen to be available at the time.

(5) Sensation seeking. The sensation seeking personality trait refers to people's tendency to be stimulated by risky, exciting activities (Zuckerman, 1994; Berlyne, 1974; Möller \& Huber, 2003). It is assumed that individuals strive for an optimal level of activation, which varies from one person to the next. Not achieving or surpassing this level is perceived as unpleasant. By seeking out stimulation or avoiding stimulation, the individual attempts to reach his or her activation optimum. Since equities also entail arousal potential, shares are an appropriate means of increasing the activation level. In this sense, Wärneryd (2001) has made the direct comparison to gambling. Harlow and Brown (1990) showed that sensation seekers also generally prefer riskier forms of investment. In some cases—similar to problem gambling — the thrill-seeking can take on a compulsive character.

\section{Why Private Investors Invest}

\section{Theses: Financial Investment as a Game}

Research insights, gained in part empirically and in part experimentally, have shown that the deviations from the assumptions that underlie capital markets theory are systematic, robust, and fundamental (DeBondt, 1998; DeBondt \& Thaler, 1994). The assumptions are deficient since beyond the postulated economic motive of striving for profits, non-economic motives-whether psychological or socio-psychological by nature-are either not considered at all or they are not completely translated into economic variables. Modern capital markets theory has little to say about such significant aspects of behavior on capital markets like values and norms, mass psychological processes, or activation and sensation-seeking. To supplement economic explanation approaches, the following suggests a perspective to in part integrate such aspects, of course without abandoning the relative dominance of economic considerations. The focus lies on investigating the motives that prompt private investors to invest their money in shares on capital markets. For this, the following theses are put forward, and then subsequently reviewed empirically:

Thesis 1: Certain financial investment decisions such as engagement on the stock market have the characteristics of gaming.

Thesis 2: These characteristics motivate people to trade in stocks. 
Thesis 3: Certain financial investment decisions that must be viewed as gambling.

These theses do not postulate that every private investment decision is reached purely for the entertainment value or simply to play (This may apply to some transactions, but such cases are rarely observed). What these indicate is that, beyond economic aspects, financial investment decisions involving equities also exhibit aspects of a game or gambling to a significant extent, which is why such investments are selected.

\section{Characteristics of Playing}

Almost all psychological game theories attribute an important role to play in human development and being human in general (Benesch, 1980). Playing is not the opposite of working or a behavior that applies to childhood (Scheuerl, 1973). It is much more a core element for learning individuals and a lifelong process in human existence. Thus, playing is neither irrational nor unreasonable. Nor is it possible to separate play from the everyday (Dörner, 2004).

Financial investment decisions have the character of serious and competitive games because they follow an explicit and carefully thought out purpose. They do not primarily serve as entertainment and they can entail significant (financial) consequences (Clark, 1971). Financial investment decisions are competitive games to the extent that they describe situations that encompass contradictory interests, they presume specific knowledge, and they allow for a choice among various potential moves or decisions.

To date, there is neither a comprehensive theory nor a comprehensive, uniform paradigm that includes all possible game forms. However, games can be described based on several qualities (Abt, 1971; Kirchdorfer, 1986; Scheuerl, 1973):

Incentive structure: Gains and losses form the incentive structure for competitive games in stock trading.

Social context: Competitive games are social events. Each player considers other people and their expectations, objectives, and strategies in his or her decisions.

Excitement and simulation: The threat of losing stakes in the game and the prospects of wining generate stress and potential thrill. This tension is proactively sought out in the game and perceived as pleasant.

Skill development: In the game, individual capabilities are put to the test. Beyond this, skills can also be developed further. In this way, the stock exchange can also serve as a playing field to develop competencies.

Creative action: Beyond rational-analytical components, serious games always have creative ones as well. Not infrequently, success in the game depends on the creativity of the strategies developed and on the originality of how other players are involved.

\section{A Study to Survey the Motives Behind Financial Investment Decisions}

\section{Study Setup and Random Sample}

Based on a random survey of the German population that included 1,017 individuals, the thesis that trading stocks could be viewed as a game was subject to empirical validation (Raab \& Neuner, 2004). The survey was conducted with computer support via telephone and was handled by a professional research institute. Survey content included financial investment behavior, motivations to invest in shares, and the appraisal of own and external expertise regarding the assessment of risk associated with shares.

Shareholders were asked why securities appeal to them. If such investments have the character of a game, then such engagements should stem from the same motives that prompt individuals to play a game. Financial investment decisions should then also be explainable using the characteristics stated above. 


\section{Results}

Respondents were asked the following questions: "Why do securities appeal to you?” (Five response categories were provided). The economic motive was covered by the response category of potential profits. The response category that one should hold stocks these days pointed to a social motive. The motive of excitement and stimulation was reflected in the category of sensation-seeking. Agreement with the category of one's own knowledge would indicate the competence motive. Finally, the category of having influence over the company would point to the motive of shaping things and creative action. Respondents were free to indicate one or more categories. They did not need to agree with any categories. Figure 1 shows how those surveyed responded.

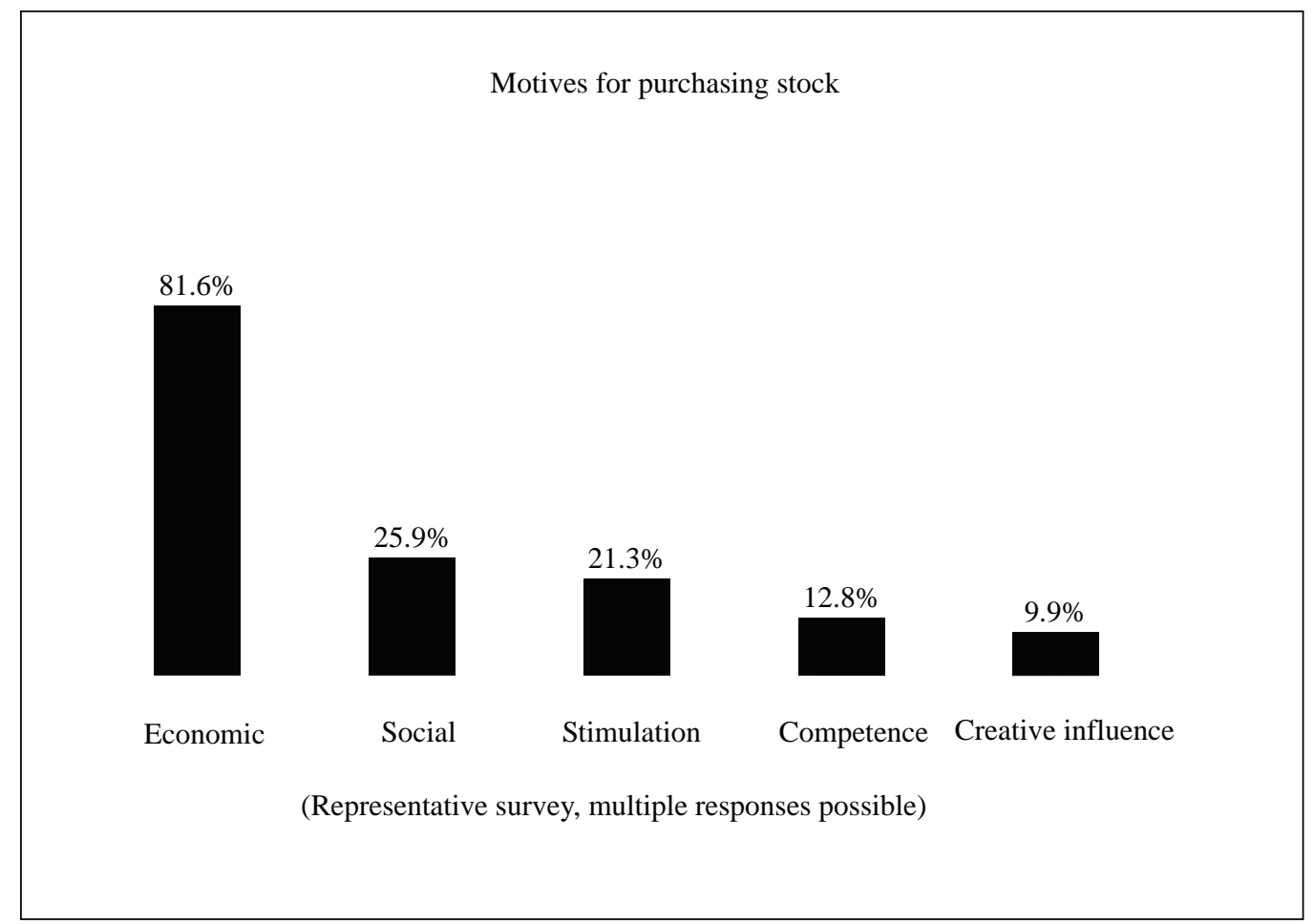

Figure 1. Motives for purchasing stock (1).

If one assumes the homo economicus archetype, then investors would only be interested in potential returns. As expected, the economic motive is also predominant in this study. However, other motives were also stated. Almost 20 percent of respondents did not indicate the economic motive. The picture gains even more clarity when one asks how many of the investors decide exclusively based on the economic motive as shown in Figure 2. For over $50 \%$ of the respondents, the economic motive of making a profit is only one reason among others.

The second most frequent response is the social motive. The status of this behavior is less important for the purpose of the study than the proliferation. Whether this is a manifestation of a self-esteem deficit or an expression of the herd instinct is less important here. What is decisive is that a quarter of investors responding also own shares because others invest their money in shares that they should be investing in.

Excitement, activation, and thrills are consciously sought out by a fifth of shareholders. What is interesting in this context is that this motive is predominantly important for men. While 78 percent of men invest their money in stocks for reasons of stimulation and excitement only 22 percent of the women respondents did so 
(see Figure 2). Similar results have also been stated by Kuchner and Meitner (2004) and Fossen (2012).

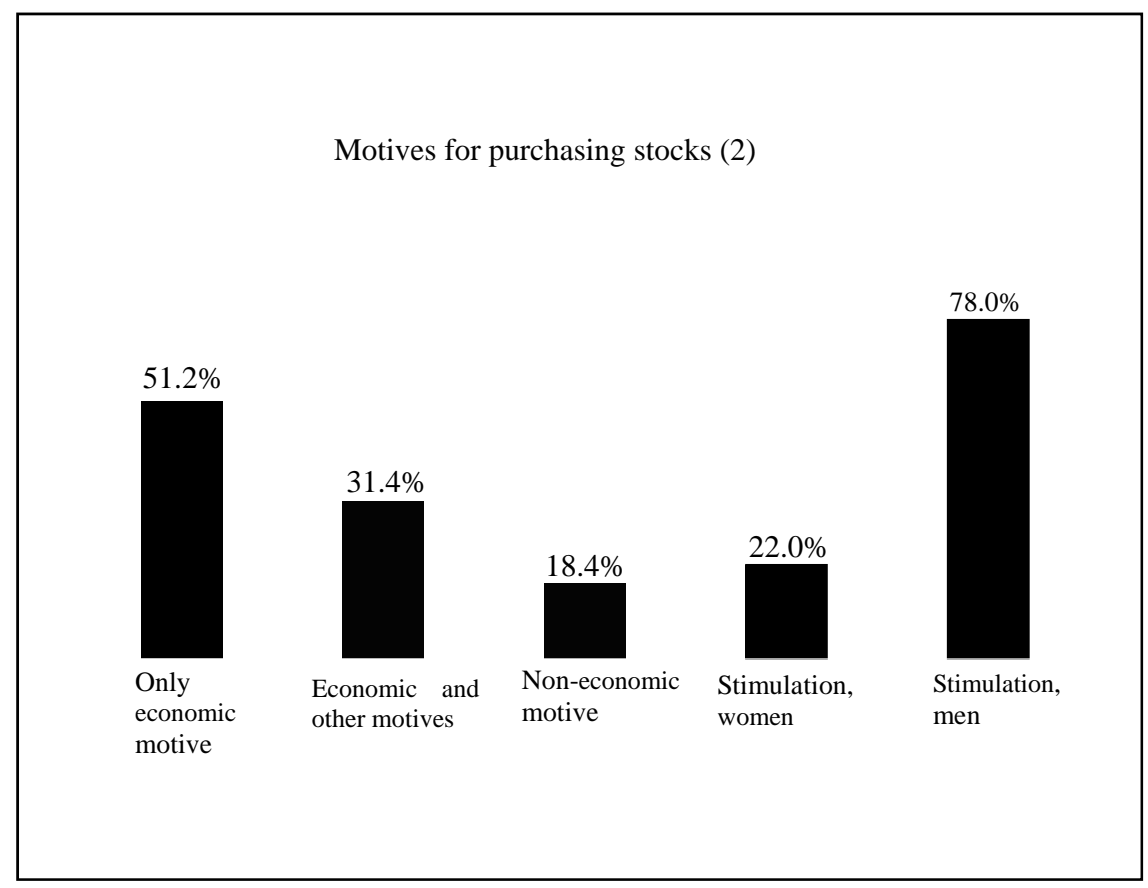

Figure 1. Motives for purchasing stocks (2).

Less significant are the two remaining motives. For almost 13 percent, the motive derived from a desire for competence and shaping opportunities is a reason to buy stock. The fundamental desire for opportunities to shape and influence is also associated with the competence motive. At almost 10 percent, the motive of influencing has the least significance.

With reference to theses formulated above, it can be ascertained that investors do not invest in stock solely based on economic motives. Other motives exist, which in part also contribute substantially to explaining the engagement of private investors on the stock market. Generally, other motives also explain gaming behavior among people.

Do these results suggest that German investors view their investment decisions as gambling? Forms of financial investments like commodities futures and in part shares have the character of gambling to the extent that both forms of investment offer high prospective profits. Investors, however, (first) have little or no objective possibility to influence the development of their investment, and (second), the probability of profits or losses is unknown ex ante. On securities markets, the largest share of trading volume by far is speculative. The profit or loss depends on circumstances that the private investor usually cannot influence (Wärneryd, 2001). Share prices follow a random walk and specific price trends are generally unpredictable (Fama, 1998; Pierdzioch \& Stadtmann, 2003). In this sense, involvement in stock markets is highly similar to gambling.

Although overall German investors are more risk-averse than average (Goerke \& Pannenberg, 2012), many investors feel that they can correctly assess the risk associated with stocks. Investors holding risky and highly risky forms of investment such as commodities futures are particularly convinced of their own capabilities and those of experts (see Figure 3). 


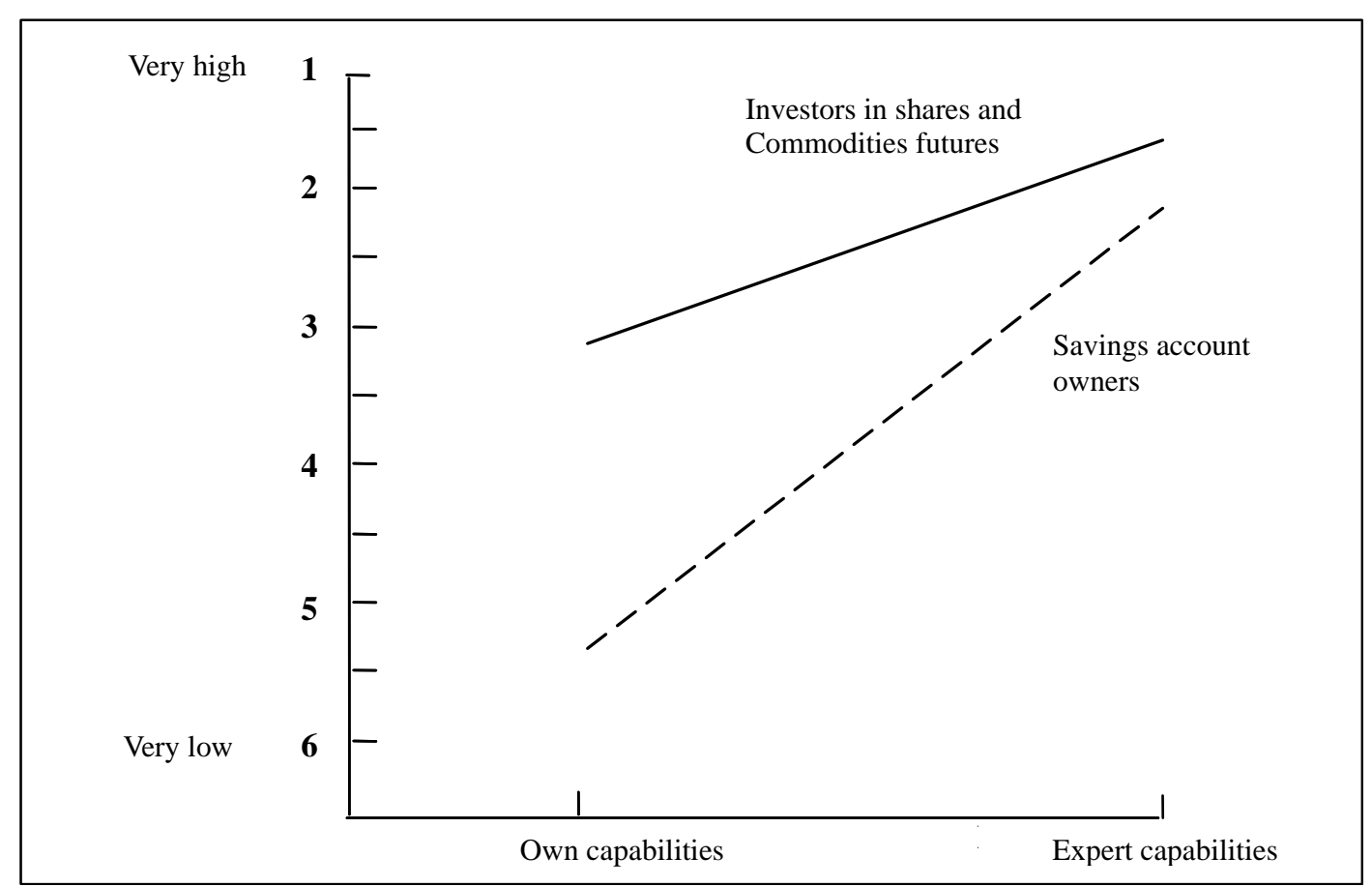

Figure 3. Overestimation of capabilities among investors holding different forms of investment.

\section{Conclusions}

In today's lecture halls students still learn that comprehensively informed economic subjects interact on capital markets who expect to maximize their benefit and are just as immune to feelings as they are to the decisions of others. The objective of this article was to show that psychological considerations can help to better understand financial investment decisions. Attempting to explain financial investment decisions within the homo economicus model would mean that the economic motive would be of sole importance. What was, however, empirically demonstrated is that although the economic motive indeed is important, by no means is it the only one? Beyond the economic motive, it is predominantly the stimulation motive that has particular significance, and this especially applies to the investment behavior of men.

This article showed that for typical German investors, stock market transactions are motivated similarly to games, and that the number of importance of such motives is increasing. As the results of this study, and others, there is a growing willingness in economic research to integrate insights from the behavioral sciences. The openness in practice is also gaining ground (Deutsche Bank, for example, has established a dedicated behavioral finance unit in response to this trend).

These findings have implications for financial institutions and for consumer policy. It would be in the interests of financial institutions and markets to contribute to this effort. Advising provided by financial institutions will thus gain in importance because the Internet's capabilities not only underscore the opportunities associated with financial investments, but also promote their gaming character (Lester, 1994).

In summary, the findings suggest that the traditional model to forecast and explain share prices in capital markets research should be revised to take into consideration the systematic behavioral anomalies outlined. 


\section{References}

Abt, C. C. (1971). Ernste spiele. New York.

Barber, B. M., \& Odean, T. (2001). Boys will be boys: Gender, overconfidence, and common stock investment. Quarterly Journal of Economics, 116, 261-292.

Becker, G. S. (1994). A treatise on the family. Cambridge, M.A.: Harvard University Press.

Benesch, H. (1980). Spiel als therapeutische alternative, Tübingen.

Berlyne, D. E. (1974). Conflict, arousal, and curiosity. New York: McGraw-Hill.

DeBondt, W. F. M. (1998). A portrait of the individual investor. European Economic Review, 42, 831-844.

DeBondt, W. F. M., \& Thaler, R. H. (1994). Financial decision-making in markets and firms: A behavioral perspective. Cambridge, M.A.: National Bureau of Economic Research.

Dörner, D. (2004). Die logik des misslingens. Rowohlt: Reinbek bei Hamburg.

Fama, E. F. (1970). Efficient capital markets: A review of theory and empirical work. Journal of Finance, 25, 383-417.

Fama, E. F. (1998). Market efficiency, long-term returns, and behavioral finance. Journal of Financial Economics, 49(3), 283-306.

Feather, N. T. (1959). Subjective probability and decision under uncertainty. Psychological Review, 66, 150-164.

Fossen, F. (2012). Gender differences in entrepreneurial choice and risk aversion-A decomposition based on a microeconometric model. Applied Economics, 44(14), 17905-1803.

Goerke, L., \& Pannenberg, M. (2012). Risk aversion, collective bargaining, and wages in Germany. Labour, 26(2), 156-173.

Griffin, D. W., \& Varey, C. A. (1996). Towards a consensus on overconfidence. Organizational Behavior and Human Decision Processes, 65, 227-237.

Hamm, H. (2008). Housing finance in Germany: A stable funding scheme model. Housing Finance International, 23(2), 44-49.

Harlow, W. V., \& Brown, K. C. (1990). Understanding and assessing financial risk tolerance: A biological perspective. Financial Analysts Journal, 46, 50-62.

Hillen, B. (2003). Ein theoretischer nachruf: Der homo oeconomicus ist tot. Sparkasse, 120, 341.

Huizinga, J. (1938). Homo ludens: Vom ursprung der kultur im spiel. Reinbek bei Hamburg: Rowohlt.

Kahneman, D., \& Tversky, A. (1972). Subjective probability: A judgment of representativeness. Cognitive Psychology, 3, 430-454.

Kahneman, D., \& Tversky, A. (1973). On the psychology of prediction. Psychological Review, 80, 237-251.

Kahneman, D., \& Tversky, A. (1974). Judgment under uncertainty: Heuristics and biases. Science, 185, 1124-1131.

Kahneman, D., \& Tversky, A. (1979). Prospect theory: An analysis of decision under risk. Econometrica, 47, $263-291$.

Kahneman, D., \& Tversky, A. (1981). The framing of decisions and the psychology of choice. Science, 222, 453-458.

Kahneman, D., \& Tversky, A. (1991). Loss aversion and riskless choice: A reference dependent model. Quarterly Journal of Economics, 106, 1039-1061.

Kiehling, H. (2001). Börsenpsychologie und behavioral finance: Wahrnehmung und Verhalten am Aktienmarkt. München: Verlag Vahlen.

Kirchdorfer, A. M. (1986). Psychologie von spiellust und kontrolle—Das spielverhalten. München: Bayerischer Monatsspiegel.

Kirchgässner, G. (2001). Homo oeconomicus: Das ökonomische modell individuellen verhaltens und seine anwendung in den wirtschafts—Und sozialwissenschaften. Tübingen.

Langer, E. J. (1975). The illusion of control. Journal of Personality and Social Psychology, 32, 311-328.

Langer, E. J., \& Roth, J. (1975). Heads I win, tails its chance: The illusion of control as a function of the sequence of outcomes in a purely chance task. Journal of Personality and Social Psychology, 32, 951-955.

Lester, D. (1994). Access to gambling opportunities and compulsive gambling. International Journal of Addictions, 29, 1611-1616.

Lichtenstein, S., Fischhoff, B., \& Philips, L. D. (1982). Calibration of probabilities: The state of the art in 1980. In D. Kahneman, P. Slovic, \& A. Tversky (Eds.), Judgement under uncertainty: Heuristics and biases (pp. 306-334), Cambridge: Cambridge University Press.

Lintner, J. (1965). The valuation of risk assets and the selection of risky investments in stock portfolios and capital budgets. The Review of Economics and Statistics, 47, 13-37.

Manstetten, R. (2000). Das menschenbild der ökonomie-Der homo oeconomicus und die anthropologie von Adam Smith. München, Freiburg: Verlag Karl Alber. 
Möller, A., \& Huber, M. (2003). Sensation seeking—Konzeptbildung und-Entwicklung. In M. Roth, \& P. Hammelstein (Eds.), Sensation Seeking -Konzeption, Diagnostik und Anwendung (pp. 5-28). Göttingen: Marcus Roth und Philipp Hammelstein.

Mossin, J. (1966). Equilibrium in a capital asset market. Econometrica, 34, 768-783.

Nitzsch, R. V., \& Friedrich, C. (1999a). Entscheidungen in finanzmärkten: Psychologische grundlagen. Aachen: Mainz Verlag.

Nitzsch, R. V., \& Friedrich, C. (1999b). Erkenntnisse der verhaltenswissenschaftlichen kapitalmarktforschung-Behavioral finance. Sparkasse, 116, 497-505.

Nitzsch, R. V., Friedrich, C., \& Pulham, S. (2001). Investor relations aus der perspektive der behavioral finance. In A. Christin, \& A. Bassen (Eds.), Investor relations am Neuen markt: Zielgruppen, instrumente, rechtliche rahmenbedingungen und kommunikationsinhalte (pp. 143-158), Stuttgart.

Oehler, A. (1992). Anomalien, irrationalitäten oder biases der erwartungsnutzentheorie und ihre relevanz für finanzmärkte. Zeitschrift für Bankrecht und Bankwirtschaft ZBB, 2, 97-124.

Pelzmann, L. (2000). Wirtschaftspsychologie-Behavioral economics. Wien: Springer.

Pierdzioch, C., \& Stadtmann, G. (2003). Kapitalanlage. Sparkasse, 120, 36-39.

Raab, G., \& Neuner, M. (2004). Motive für geldanlageentscheidungen und privater investoren. In W. Bungard, B. Koop, \& C. Liebig (Eds.), Psychologie und wirtschaft leben (pp. 532-539), München.

Rossbach, P. (2001). Behavioral finance: Eine alternative zur vorherrschenden kapitalmarkttheorie? Paper No. 31 der Hochschule für Bankwirtschaft, HfB, Frankfurt am Main.

Scheuerl, H. (1973). Das spiel, untersuchung über sein wesen, seine pädagogischen möglichkeiten und grenzen. Weinheim: Beltz.

Sharpe, W. F. (1964). Capital asset prices: A theory of equilibrium under conditions of risk. Journal of Finance, 19, 425-442.

Shefrin, H. (2000). Beyond greed and fear: Understanding behavioral finance and the psychology of investing. Boston: Harvard Business School Press.

Shiller, R. J. (1997). Human behavior and the efficiency of the financial system. In J. B. Taylor, \& M. Woodford (Eds.), Handbook of macroeconomics. Princeton: Princeton University Press.

Shiller, R. J. (2003). From efficient markets theory to behavioral finance. Journal of Economic Perspectives, 17(1), 83-104.

Smith, A. (1776). An inquiry into the nature and causes of the wealth of nations. London: Printed for W. Strahan.

Stotz, O., \& Nitzsch, R. V. (2002). Warum sich Analysten überschätzen: Ergebnisse einer empirischen Untersuchung. Forschungsbericht 02/02v1 am Forschungsinstitut für Asset Management RWTH Aachen, Aachen.

Stracca, L. (2004). Behavioral finance and asset prices: Where do we stand? Journal of Economic Psychology, 25(3), 373-408.

Wärneryd, K. E. (2001). Stock-market psychology: How people value and trade stocks. Cheltenham: Edward Elgar Publishing.

Wunderlich, W. (1989). Der literarische Homo oeconomicus: Allegorie und Figur. In W. Wunderlich (Ed.), Der literarische Homo oeconomicus: vom Märchenhelden zum Manager: Beiträge zum Ökonomieverständnis in der Literatur (pp. 9-21). Bern: Haupt.

Zuckerman, M. (1994). Behavioral expressions and biosocial bases of sensation seeking. New York: Cambridge University Press. 